Review

\title{
Supply Chain Configurations in the Circular Economy: A Systematic Literature Review
}

\author{
Donato Masi, Steven Day * and Janet Godsell \\ Warwick Manufacturing Group, University of Warwick, Coventry CV4 7AL, UK; \\ donato.masi@warwick.ac.uk (D.M.); j.godsell@warwick.ac.uk (J.G.) \\ * Correspondence: S.J.Day@warwick.ac.uk; Tel.: +44-7778-457659
}

Received: 31 July 2017; Accepted: 2 September 2017; Published: 7 September 2017

\begin{abstract}
As the circular economy (CE) gains traction in literature and practice, several academic communities are opening up spaces that move away from the $\mathrm{CE}$ as a pure engineering concept. This systematic literature review $(n=77)$ analyses and discusses the fragmented body of knowledge on the meso-level of supply chains (SCs): (a) to find common ground that underpins the current implementation of the $\mathrm{CE}$ on this level; and (b) to identify drivers, inhibitors, and enablers from which CE SC configurations emerge. The review finds that there remain differences in CE definitions that result from claimed antecedents and scopes, resulting in distinct research streams. On the meso-level, eco-industrial parks, environmental SCs, and closed-loop SCs each face significant challenges. The latter potentially offers the largest environmental benefits but engenders radical changes for business models and exposes SCs to more risk. We firstly argue for moving away from using a prescriptive set of practices as definitions for the $\mathrm{CE}$ towards a set of overarching goals to allow for the inclusion of future practices and techniques. Secondly, we highlight that research going beyond the meso-level to consider the wider social and institutional environment is needed to solve current challenges.
\end{abstract}

Keywords: circular economy; literature review; sustainable supply chains; closed-loop supply chains; industrial ecology

\section{Introduction}

The linear model of resource consumption, based on the "take-make-consume-dispose" pattern, does not appear to be sustainable as it depletes the natural capital and pollutes the environment $[1,2]$. To give an indication of the magnitude of this problem, recent studies suggest that the world's cities generate about 1.3 billion tonnes of solid waste per year, which will increase to 2.2 billion tonnes by 2025 , resulting in an annual cost of $\$ 205.4$ billion today and an estimated cost of $\$ 375.5$ billion in 2025 [3].

From a business perspective, this development is reshaping competitive priorities for firms and supply chains (SCs). On the production side, increasing resource scarcity leads to rising resource prices and price volatility, which impact negatively on firms' profitability [4]. Incremental improvements through more efficient processes have been questioned because of the "rebound effect", which describes how the environmental benefits of energy and materials' efficiency gains might be offset by increased production and utilization of a good [5], and thus calls are growing for more transformative changes in how firms do business. Similarly, there are changes on the demand side: consumers are increasingly demanding environmental responsibility of firms and SCs [6]. On a fundamental level, consumer preferences are shifting, and business models based on ownership are competing with new ones based on the concept of ownership-less consumption [7,8].

The concept of the circular economy (CE) [4] is rapidly capturing attention as a potential solution for the challenges of the current competitive scenario due to its ability to create 
synergies between environmental and economic development goals. The CE seeks to replace the "take-make-consume-dispose" patterns with closed-loops of material flows [2], made possible by combining a variety of different processes, such as maintenance, repair, reusing, refurbishing, remanufacturing, and recycling [4]. A core assumption of the CE is therefore that the recovery of value from physical goods through the narrower cycles of re-use and refurbishment are superior both economically and environmentally to recycling and energy recovery [9].

To enable such cycles, SCs are assumed to be a critical unit of action for the implementation of the CE because of the necessity for joint effort "beyond organizational boundaries to involve external coordination with upstream partners to obtain environmentally friendly inputs and with downstream partners to cooperate for environmental management practices such as product return, reuse, and recycling" [10] (p. 1325). However, Circular Supply Chains (CSCs) that continuously sustain the circulation of value by combining the variety of possible CE SC configurations and are fully aligned with the principles of the $\mathrm{CE}$ are largely absent in practice and academia; instead current knowledge on SCs in the CE is fragmented between several fast-growing research streams.

This paper conducts a systematic literature review (SLR) on the CE with two objectives: the first is to synthesize what goals and assumptions about the $\mathrm{CE}$ underpin the different strands of research on the meso-level, and second to assess the state of knowledge on SC configurations and their competitive environments within the CE.

The paper is structured as follows. In Section 2, the research methodology is presented. Section 3 displays the descriptive results of the SLR, divided into publication year, journal, and article topics, after which Section 4 gives an overview of the thematic results. These results are discussed in Section 5 , and Section 6 provides a brief conclusion to this paper.

\section{Review Methodology}

In order to avoid the perceived weaknesses of narrative reviews [11], this study adopts a systematic or evidence-informed approach based on the five-step approach drafted by Denyer and Tranfield [12]. These five steps are illustrated in Figure 1.

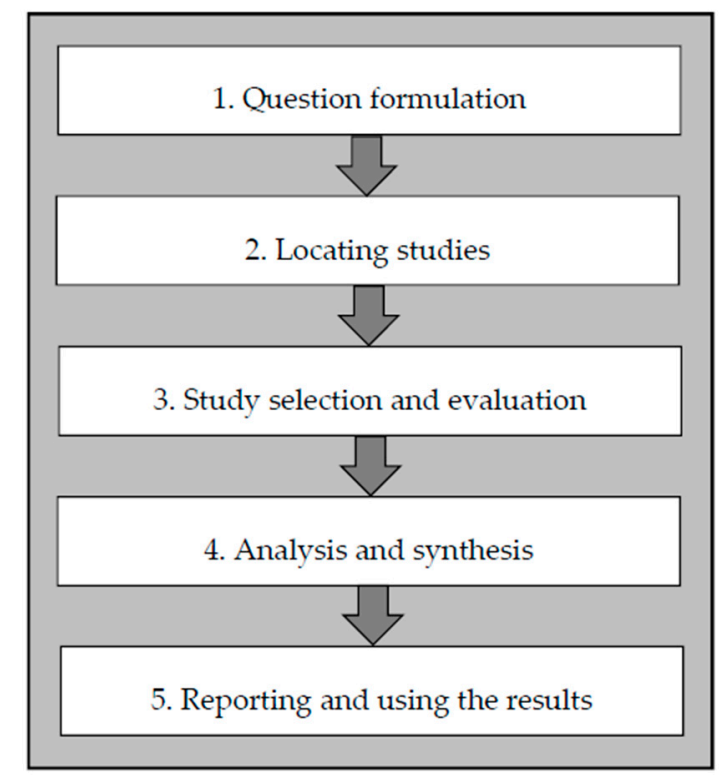

Figure 1. Systematic literature review approach (adapted from [12]).

\subsection{Question Formulation}

Given the aforementioned fragmentation of CE research in regard to SCs, this study attempts to structure the current findings using an SLR methodology. To this end, the review questions therefore 
ask: (a) what overarching goals and assumptions define the CE; (b) what practices are described as being part of the meso-level of SCs in the CE; and (c) what conditions are necessary for such SCs to emerge in the $\mathrm{CE}$.

\subsection{Locating Studies}

After consulting a database expert with significant experience in supporting faculty with conducting SLRs, three databases with the highest coverage for the researched topic were identified: "Web of Science", "Scopus" and "ProQuest". The search strings used are given in Table 1. Search strings were designed deliberately broad to ensure articles related to SCs in the CE were located, given that the CE is a relatively new topic lacking clearly distinguished research areas. The search was limited to articles from scholarly, peer-reviewed journals in English with no time restrictions. The resulting number of papers was 215 (Web of Science), 75 (Scopus), and 153 (ProQuest). All searches were performed on 18 June 2017.

Table 1. Search strings used in each of the databases.

\begin{tabular}{|c|c|c|}
\hline Database & Search String & Application of Search String in Database \\
\hline $\begin{array}{l}\text { Web of Science } \\
\text { (Core Collection) }\end{array}$ & $\begin{array}{l}\left(\mathrm{TS}=\left(\left(\text { circular econom }^{*}\right) \text { AND (supply chain OR }\right.\right. \\
\text { (production AND operation*) OR Industrial OR } \\
\text { manufactur*)) AND LANGUAGE: (English) AND } \\
\text { DOCUMENT TYPES: (Article) }\end{array}$ & $\begin{array}{l}\text { "TS }=\text { " refers to Web of Science's search in titles, } \\
\text { abstracts and keywords. A "*" means that any } \\
\text { suffix/prefix can be added at the place of *. } \\
\text { The search resulted in } 215 \text { papers. }\end{array}$ \\
\hline Scopus & $\begin{array}{l}\text { TITLE-ABS-KEY((circular AND econom*) AND } \\
\text { (supply AND chain OR (production AND } \\
\text { operation*) OR industrial OR manufactur*)) AND } \\
\text { (LIMIT-TO (DOCTYPE,“ar")) AND (LIMIT-TO } \\
\text { (LANGUAGE,“English”)) }\end{array}$ & $\begin{array}{l}\text { TITLE-ABS-KEY refers to SCOPUS's search in titles, } \\
\text { abstracts, and keywords. The meaning of a "** is the } \\
\text { same as above. } \\
\text { The search resulted in } 75 \text { papers. }\end{array}$ \\
\hline ProQuest & $\begin{array}{l}\text { (ti(circular econom*) AND (supply chain OR } \\
\text { (production AND operation*) OR Industrial OR } \\
\text { manufactur*) OR ab(circular econom*) AND } \\
\text { (supply chain OR (production AND operation*) OR } \\
\text { Industrial OR manufactur*) AND LANGUAGE: } \\
\text { (English)) AND (at.exact("Article") AND } \\
\text { stype.exact("Scholarly Journals") AND PEER(yes)) }\end{array}$ & $\begin{array}{l}\text { "ti" and "ab" refer to ProQuest's search in titles and } \\
\text { abstracts. The meaning of a "*" is the same as above. } \\
\text { The search resulted in } 223 \text { papers. However, after } \\
\text { further refinement according to the following } \\
\text { categories: economics OR circularity OR recycling OR } \\
\text { sustainable development OR waste management OR } \\
\text { environmental management OR environmental } \\
\text { economics OR industrial development OR } \\
\text { manufacturing OR supply chains OR supply chain } \\
\text { management OR life cycle analysis OR business OR } \\
\text { economic models, there were } 153 \text { papers remaining. }\end{array}$ \\
\hline
\end{tabular}

\subsection{Study Selection and Evaluation}

Given the multifaceted nature of the CE concept, titles and abstracts, and subsequently full contents of the papers were reviewed for selection. Inclusion and exclusion criteria were developed after an initial full text screening of recent on CE-related research articles and applied to the title and abstract screening, as well as the full text screening. Inclusion criteria were developed to specify which articles would be taken forward in the review process:

- Conceptual studies that explore and define the CE on an abstract level. This criterion is related to the first research question; exemplary studies discuss definitions and antecedents of the CE.

- Conceptual and empirical studies on implementation of the CE on the micro- or meso-level of firms and SCs. This criterion emerged from the second and third research questions, assuming that non-empirical studies might still provide insight into this relatively young research area.

- Studies that identify drivers and barriers to the implementation of the CE. This criterion similarly aims at the third research question and acknowledges the interconnectedness of the $\mathrm{CE}$-if there are barriers on other levels than the meso-level, these might still impact on the development of the CE on that level.

Similarly a number of exclusion criteria were developed: 
- Empirical studies on implementation of the CE on the macro-level (cities, regions, industries) that do not refer to how this impacts on or is to be supported by the meso-level. Such studies do not help in answering the second or third research questions as they tend to focus on the design and implementation of a top-down policy on a different level of an analysis.

- Technology and process innovation research that is disconnected from commercial applicability. These studies, while contributing to the implementation of the CE by providing its technological base, are not useful in answering the research questions as their operationalization in SCs or business models is not considered.

- Descriptions of quantitative models targeted at individual industries. While these models provide insight into how individual industries might work under a CE paradigm, they do not offer insight into how such a paradigm is to be implemented on the meso-level.

Application of these criteria, in addition to removing duplicate articles, reduced the number of papers for analysis to 68 . An additional nine articles were added through cross-referencing based on the inclusion criteria. The final number of reviewed articles is 77, as depicted in Figure 2.

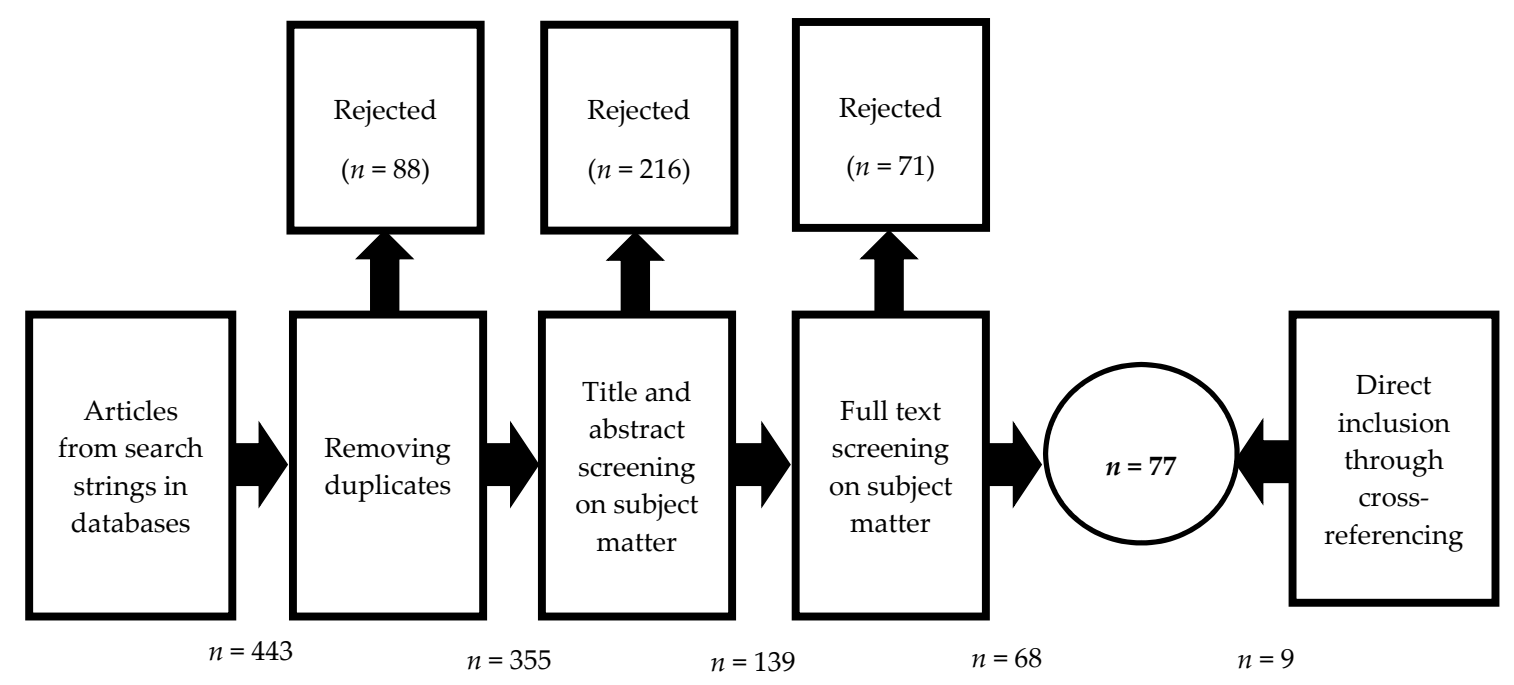

Figure 2. Overview of article screening process with resulting number of articles.

\subsection{Analysis and Synthesis}

Each of the 77 papers was analysed for both its descriptive and thematic content by two of the three reviewers, who both reviewed a sizeable sample of the papers before discussing their findings and then split the papers between them. This ensured they were interpreting the content similarly. The descriptive analysis focused on the categorization of papers by year and journal, and the main topic of each paper. The thematic analysis then established common ground among the plethora of different understandings and definitions of the CE.

Afterwards, the practical perspective presents the way in which the $\mathrm{CE}$ is currently being framed and implemented with a focus on SCs.

\subsection{Reporting and Using the Results}

The remainder of this paper is dedicated to reporting the results descriptively and thematically, and to the discussion of the findings' application to both academia and practice. 


\section{Descriptive Results}

The 77 identified articles are analysed in this section in regard to publication year, journal, and topic, to understand trends in the body of knowledge on the interchange of the CE and SCs.

\subsection{Publication Years}

The papers were published from 2005 onwards. A small intermittent peak is apparent in 2011 when seven papers were published before dropping to three in 2013. Despite a cut-off point in mid-2017, this year nevertheless marks the most publications at 19, which indicates a strong growth trend, as indicated in Figure 3.

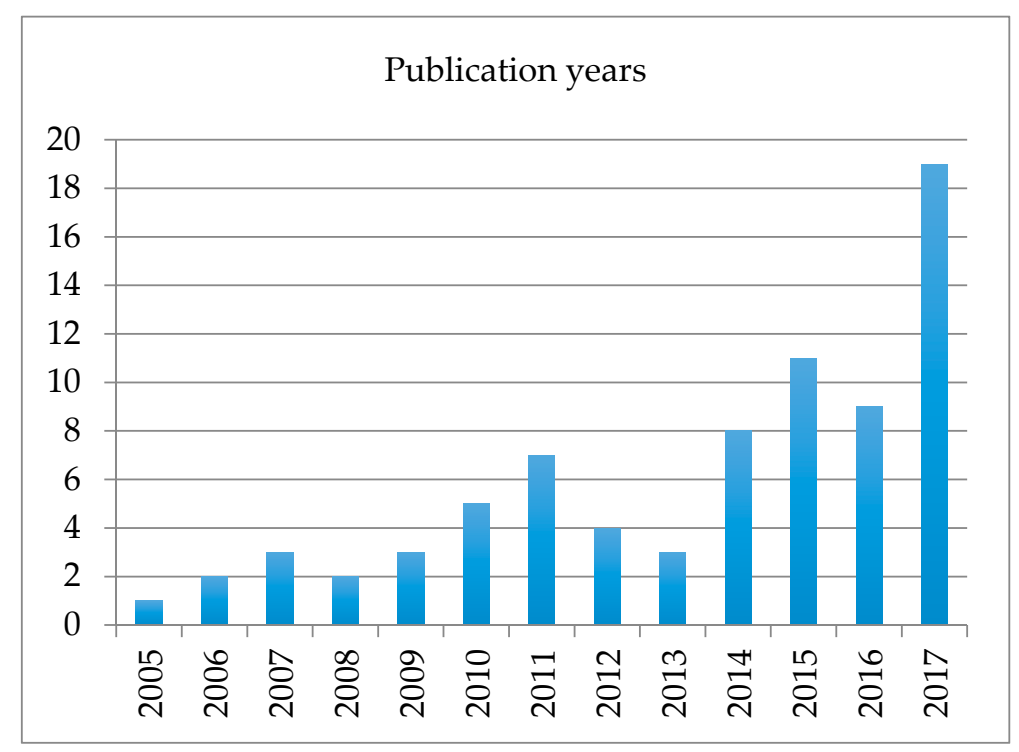

Figure 3. Publication year of selected papers.

Interest in the $\mathrm{CE}$ as a concept was originally driven by the anticipation that China would enact specific CE legislation in 2007 or 2008, after having shown interest since 2002 [13], which resulted in a variety of implementation studies and evaluations post-2008. In Western-centric research, the Ellen MacArthur Foundation (EMF) and ensuing interest from the British government, has generated enthusiasm among academia for the concept from 2013 onwards [2,14,15]. It is therefore expected that the annual number of publications will continue to rise in the Western academic community especially.

\subsection{Targeted Journals}

The 77 identified papers were published in 32 journals. Four journals published three or more articles on the topic and these journals published 42 articles between themselves, as shown in Figure 4 . The Journal of Cleaner Production contributed less than a third of the total at 24 publications and the Journal of Industrial Ecology a seventh at 11. While these two journals have consolidated the field to some extent, this nevertheless means that the majority of journals published only one or two articles on the subject, indicating a persistent fragmentation in the scholarly literature. 


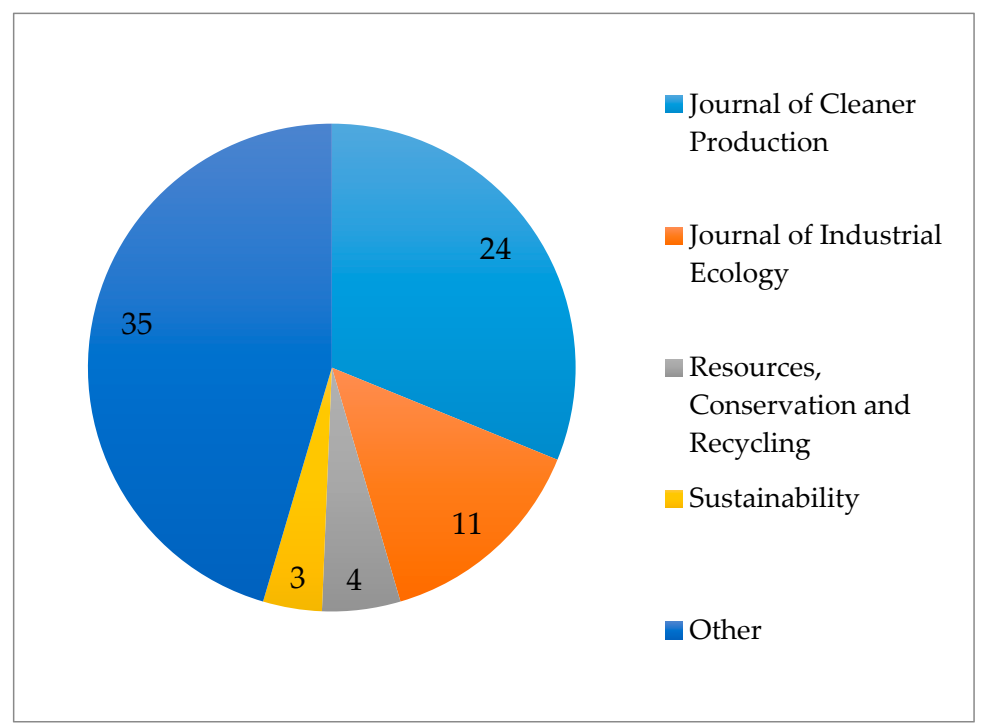

Figure 4. Articles sorted by journals.

This can be partially explained by the studies on CE conceptualization and implementation in China. The early focus on the cleaner production, industrial ecology and symbiosis aspects of the concept was determined by the Chinese authorities' decision to first implement cleaner production legislation and then transition towards a CE characterized by eco-industrial park (EIP) pilot projects that followed industrial symbiosis principles [13,16,17], which is mirrored in the journals targeted by authors. Later publications depart from this framing of circular "as a pure engineering system" [18] (p. 8) by putting more emphasis on the economic and social dimensions [2,15], leading to a diversification of targeted journals and covered topics.

\subsection{Article Topics}

The majority of articles can be classified as implementation studies, with an emphasis on case studies of predominantly Chinese eco-industrial initiatives at the meso-level of EIPs [17,19-29] or SCs and networks $[6,10,30-43]$. Studies on the macro-level of cities [44-46], economic areas [47,48], and national and global industries, particularly logistics and waste [7,14,49-52], were only included if they informed implementation on the meso-level, as per the inclusion and exclusion criteria. Other implementation studies focus on reviewing and informing policy $[13,16,17,53-67]$, specifically on product design for the CE $[8,9,14,64-66]$ as well as assessments of firms' $[67,68]$, consumers' [69-71], and officials' [72] awareness of and attitudes towards the CE's concepts and its components. Two contributions are concerned with business model research [73,74]. More abstract studies seek to define the CE more clearly and assess its future challenges [75-78] or highlight the social $[2,15,79,80]$ or economic aspects of the concept further $[1,18]$. Lastly, two studies explore the interchanges between the CE and information technology (IT) and waste [81] and the CE and global waste streams [82]. Furthermore two literature reviews were included that provide a birds-eye view of the antecedents and challenges of the CE on a variety of levels [83] and on the manufacturing aspect of the CE [84]. This initial result highlights that the $\mathrm{CE}$ is being understood as an integrated concept in academia, with a variety of authors making contributions that impact on the implementation at the meso-level.

\section{Thematic Results}

The following will present the thematic results of the SLR, divided into an initial survey of CE definitions offered in the literature, in order to establish common ground in current understandings of the concept. Drivers, inhibitors, and enablers of the $\mathrm{CE}$, which in the literature engender three possible $\mathrm{SC}$ configurations that employ a mix of $\mathrm{CE}$ practices, are given afterwards. 


\subsection{Defining the Circular Economy}

An initial result from the analysis of the literature is that there are fundamental differences in the way the CE is defined. Table 2 gives an overview of definitions.

Table 2. Overview of Circular Economy (CE) definitions from 2006-2017.

\begin{tabular}{|c|c|}
\hline Author & Definition \\
\hline Yuan et al., 2006 [13] & $\begin{array}{l}\text { "Although there is no commonly accepted definition of CE so far, the core of CE is the } \\
\text { circular (closed) flow of materials and the use of raw materials and energy through } \\
\text { multiple phases." }\end{array}$ \\
\hline Geng et al., 2009 [44] & $\begin{array}{l}\text { "The concept of CE has the same essence as industrial ecology, implying a closed-loop } \\
\text { of materials, energy and waste flows ... It presents a new concept of more sustainable } \\
\text { urban economic and industrial development." }\end{array}$ \\
\hline Chen, 2009 [51] & $\begin{array}{l}\text { "To solve the contradiction of limited resources and the increased consuming desire of } \\
\text { human being[s], and to make use of natural resources rationally to achieve sustainable } \\
\text { development, the circular economic development mode follows the pattern of } \\
\text { ecological circulation and is based on the recycling of material resources." }\end{array}$ \\
\hline Park et al., 2010 [36] & $\begin{array}{l}\text { "The Chinese CE policy originated with the IE policy and is built upon the concept of } \\
\text { industrial supply chain loop closing" }\end{array}$ \\
\hline Li and Yu, 2011 [59] & $\begin{array}{l}\text { "In an attempt to mitigate these difficulties, however, China's general strategy is one of } \\
\text { sustainable development - promoting comprehensive resource conservation and } \\
\text { efficient utilization, and clean production: the circular economic model." }\end{array}$ \\
\hline Hobson, 2016 [79] & $\begin{array}{l}\text { "[The CE is] an industrial system that is restorative or regenerative by intention and } \\
\text { design ... [and] aims for the elimination of waste through the superior design of } \\
\text { materials, products, systems and business models." }\end{array}$ \\
\hline Murray et al., 2017 [2] & $\begin{array}{l}\text { "The Circular Economy is an economic model wherein planning, resourcing, } \\
\text { procurement, production and reprocessing are designed and managed, as both process } \\
\text { and output, to maximize ecosystem functioning and human well-being." }\end{array}$ \\
\hline Zink and Geyer, 2017 [18] & $\begin{array}{l}\text { "The core of the circular economy refers to three activities: reuse at the product level } \\
\text { (such as 'repair' or 'refurbishment'); reuse at the component level } \\
\text { (e.g., 'remanufacturing'); and reuse at the material level ('recycling')." }\end{array}$ \\
\hline
\end{tabular}

Based on the review, three common types of CE definition were identified: the CE as a new label for an existing concept, the $\mathrm{CE}$ as a prescriptive set of existing concepts and practices, and new definitions that go beyond previous approaches and seek to integrate economic, environmental, and social considerations. The most frequent definitions here would be the $\mathrm{CE}$ as a combination of industrial symbiosis and cleaner production (e.g., $[1,36,62,63])$, as well as more inclusive definitions of the third type (e.g., $[2,15,79])$.

However, the two underlying differences in these CE definitions are the proposed antecedents and the scope of the concept. In terms of antecedents, a number of authors identify industrial ecology $[6,14,16,18,20,32,79]$ and industrial symbiosis or metabolism $[26,35,46,52,78,82]$ as the main antecedents, and focus on the closing of resource flows in production and consumption. Others [13,45,55,62] name cleaner production to "protect the environment and prevent pollution" [45] (p. 506). Furthermore, biomimicry [2,64,72,73,76], system dynamics [78] and system thinking [2,78,79], regenerative design [14,76], cradle-to-cradle design [14,52,64,82], and zero emission [55,61,82] are also named. From a macro perspective, industrial economics [21,35], ecological economics [2,15,17,32,46,52,57,71,80], environmental economics [2,17,52], steady-state economy $[15,17,60]$ and performance economy $[8,14,32,52,76,78,79]$ are given as antecedents or inspirations.

Based on these antecedents, the scope and nature the CE is to take in reality differs between authors. While Scheepens et al. [37] describe the CE as a system that is to be transitioned to through new business models, assuming a microeconomic perspective that is claimed to be common in the Western CE research by Naustdalslid [15], Park et al. [36] and Zhu et al. [10] emphasize the CE level. Hobson [79] and others [2,32], however, assume efforts should be focused on the larger system level as they assume the CE to comprehensively reshape society and consumerism. Andrews [64], Hobson [79] 
and Murray et al. [2] thus take a macro perspective by framing the $\mathrm{CE}$ as an economic model that is opposite to the "linear economic model", or classical economics [16]. Others [17,60] follow this approach by comparing it to the steady-state economy.

To reconcile the differences in proposed antecedents and scopes of the $\mathrm{CE}$ and provide more common ground, four common goals and assumptions of the $C E$ have been identified that are proposed in conceptual articles, but which also underpin empirical work as explicit or implicit assumptions as per Blomsma and Brennan's [75] claim that while the proposed CE strategies are not new by themselves, their combination into a single concept provides a platform for academia and practice to engage constructively. We therefore propose to unify the CE concept based on its goals and assumptions rather than on its current implementation or proposed antecedents.

A first finding here is that, in the vast majority of the analysed articles, the CE aspires to become a replacement for the current (linear) economic framework and is intentionally designed to be regenerative and restorative with its individual strategies aimed at different levels of that framework $[1,2,16,64,73,76,79]$. This new economic framework is, however, unlike classical economics, assumed to be regenerative, which implies that the ecosphere is allowed to recover from the effects of polluting economic activity over time [1], or ideally restorative, which "also aims to repair previous damage" [2] (p. 5), aside from preventing such damage, e.g. pollution, in future activity. However, scope for regeneration and restoration needs be purposefully built into business models and product design $[8,9,64,65]$, production processes $[21,47,55]$ and ultimately industries $[30,44,45]$.

The immediate goal of this new economic framework is to decouple economic growth from natural resource depletion and environmental degradation $[2,10,15,17,36,45]$. Pollution and resource depletion are therefore not understood as irrelevant or unavoidable by-products of economic activity, but can and should be eliminated $[15,17,76]$. In terms of resource consumption, Li et al. [53] specify that decoupling from non-renewable energy sources is a key objective. Hobson [79] extends this and stresses that absolute, as opposed to relative, decoupling from non-renewable resources will be necessary, whereas others $[1,15]$ concede that limits to recycling prevent this—but "the intention of a CE is to work toward a closed loop" [65] (p. 517).

The third shared goal for the $\mathrm{CE}$ lies in its motivation to increase system resilience $[6,16,22,36,77,78]$. In this regard, Andrews [64] and others [50,52,79] claim that resource shortages will result in conflicts, which could be prevented by relying less on resource extraction. Webster [78] states that an economic and political system that is less dependent on external out- and inputs is overall less "brittle" and more resilient. Resource security is understood here as challenging economic growth and stability [63], and undermining national competitiveness and security in the long-term on the macro-level [57]. This goal of the CE has been largely neglected in empirical studies however.

The fourth goal aims to create and preserve economic, social, and ecological value to maximize ecosystem function and human well-being $[1,2,6,15,55,64,68,79,80]$. Authors $[2,6,15]$ therefore argue for an integration of the three in the $\mathrm{CE}$ and Geng et al. [44] claim that the " $\mathrm{CE}$ aims for simultaneous positive outcomes for the Chinese economy, society, and the environment" (p. 997) while in reality economic growth and environmental protection might often be conflicting [54]. Three aspects are especially prominent; social justice in the global economy $[2,15,79]$, declining human health because of pollution and environment degradation-an issue that is particularly prominent in Chinese CE research $[16,47,68]$, and inter-generational justice and human development taking a future perspective $[1,2,13,14,80]$.

Therefore, while a comprehensive definition of the CE catering for all the different strands on $\mathrm{CE}$ research is yet to emerge, these four goals underpin the majority of current literature on the topic explicitly or implicitly. 


\subsection{Implementing the Circular Economy}

On the level of implementation, the literature states that CE practices require cooperation across a wide range of actors that might currently be conceptualized as external to SCs. The results of the SLR in this section will therefore be presented according to the following CE SC diagram to allow for a more differentiated analysis. The idea behind the framework that was used is that there are specific drivers motivating firms to transition towards a CSC. Such a transition is made possible or impeded by a set of enablers or inhibitors, respectively. From this environment emerge SC configurations as depicted in Figure 5, which on a lower level engender certain practices.

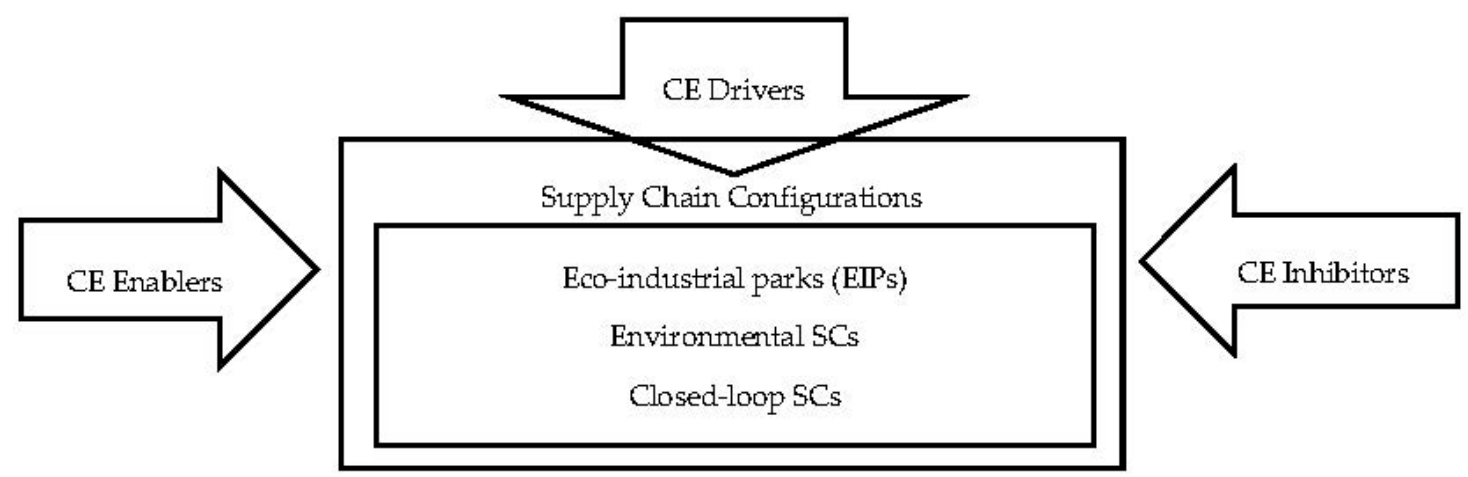

Figure 5. Environment of supply chain (SC) configurations in the Circular Economy (CE).

\subsection{Circular Economy Drivers}

While government incentives or mandatory regulation can enable some degree of transition towards the $\mathrm{CE}$, the speed of a more comprehensive shift will depend on whether decision-makers in firms believe that this will improve competitiveness [37]. From the perspective of a firm, there are a number of drivers that could motivate and reward the implementation of practices associated to circularity. Drivers are defined as reasons that might incentivize firms to proactively pursue a transition towards a CE paradigm in the way they do business. The existence and strength of these drivers is dependent on the context of the competitive environment, which will be assessed separately in the following section. Table 3 gives an overview-drivers were synthesized from the wealth of information from the literature and grouped into six broad categories.

Table 3. CE drivers from the perspective of firms and SCs.

\begin{tabular}{lll}
\hline Drivers & Comments & Authors \\
\hline $\begin{array}{l}\text { Resource efficiency gains } \\
\text { increase competitiveness }\end{array}$ & $\begin{array}{l}\text { In light of rising resource and energy prices, } \\
\text { efficiency gains translate into financial savings } \\
\text { over the long-term }\end{array}$ & {$[1,10,13,16,17,20,31,36,40,44-46,57,59,63,81]$} \\
\hline $\begin{array}{l}\text { New value streams } \\
\text { through utilization of } \\
\text { by-products and waste }\end{array}$ & $\begin{array}{l}\text { This gives a firm a new source of revenue and } \\
\text { minimizes waste treatment and disposal } \\
\text { related costs }\end{array}$ & {$[1,8,10,13,14,21,26,35-37,44,55,81]$} \\
\hline $\begin{array}{l}\text { Avoiding regulative costs } \\
\text { of environmental } \\
\text { pollution and waste }\end{array}$ & $\begin{array}{l}\text { As pollution and waste related externalities are } \\
\text { re-directed at firms, they are incentivized to alter } \\
\text { their practices }\end{array}$ & {$[10,36,45,59,63,68]$} \\
\hline $\begin{array}{l}\text { Brand reputation and } \\
\text { right-to-operate in global } \\
\text { markets }\end{array}$ & $\begin{array}{l}\text { As governments implement stricter } \\
\text { environmental regulation, firms can enter and } \\
\text { expand in markets more easily if they have } \\
\text { environmentally sound management practices }\end{array}$ & {$[7,13,14,17,31,36,45,46,57,59,74,79]$} \\
\hline $\begin{array}{l}\text { Improved brand } \\
\text { reputation with } \\
\text { consumers }\end{array}$ & $\begin{array}{l}\text { Could result in the ability to monetize } \\
\text { "green" products }\end{array}$ & {$[6,8,14,36,37,44]$} \\
\hline $\begin{array}{l}\text { Increased business } \\
\text { resiliency/reduced risk }\end{array}$ & $\begin{array}{l}\text { By avoiding dependence on price-volatile } \\
\text { resources, firms can reduce their business risk } \\
\text { on the supply side }\end{array}$ & {$[6,16,36]$} \\
\hline
\end{tabular}


On a fundamental level, resource efficiency and resource flow slowing practices result in resource and energy utilization efficiency gains, which save costs and thus contribute to a firm's competitiveness $[31,36,38]$. This assumption is also visible in the reframing of the CE from an environmental policy to an economic strategy in China [13]. A number of implementation studies thus focus on resource efficiency specifically, although actual monetary savings are commonly not given in full $[23,45]$ with a few exceptions (compare $[20,21]$ ). Increased competitiveness through reduced material and energy consumption is generally assumed rather than stated, although Ferreira et al. [31] find that firms seeking competitive advantages proactively implement CE practices-Matus et al. [54] however find that at least in some cases economic and environmental goals remain conflicting.

New value streams resulting from the exchange of by-products and waste is another motivator tied closely to industrial symbiosis [21,26]. Waste-to-energy SCs [35] or the use of sewage sludge ash in construction [55] are examples of this. On a similar note Park et al. [36] claim that there are untapped opportunities in reclaiming scarce resources in information and communications technology ICT products and that "financial value generated from these streams can be substantial" (p. 1497). Dhakal et al. [30] corroborate this by highlighting the economic potential in under-utilized secondary markets.

Curbing the emission of pollution and wastes as part of CE practices is also expected to result in lower environmental burdens associated with pollution abatement and polluter-pays mechanisms implemented by the lawmakers [36,41,45] or is done out of legal requirements [31].

Brand reputation with authorities is particularly important in China [37] and a "greener" brand might increase "legitimacy of doing business in China" [36] (p. 1498). Feng and Yan [57] (p. 97) relate this to environmental considerations in international trade and claim that "green barriers" are inhibiting access of Chinese firms to foreign markets, which is why a transition towards more environmental sustainability would be beneficial.

Improved brand reputation with consumers is another driver [34,36]. Authors are conflicted about the impact of such reputation on consumer purchasing behaviour [71,79], although it can be expected that a good reputation with consumers because of successfully communicated, environmentally friendly operations as part of CE activities is positive. Giurco et al. [14] (p. 435) state that "customer demand for responsible products has risen as environmental certification standards have grown and matured", which is corroborated by Zhu et al. [41].

One driver that has been met with conflicting views at the firm level is increasing resilience. Authors warn of price volatility resulting from uncertain resource reserves $[6,20,44]$, but while less reliance on scarce virgin resources translates into less (price) risk on the supply side, the carefully calibrated interdependence of firms in industrial symbiosis implementation projects might also create risk and uncertainty as dependency on collocated members of EIPs increases $[19,50,78]$.

\subsection{Circular Economy Inhibitors and Enablers}

The literature discusses a number of inhibitors that currently prevent the widespread adoption of CE practices by firms, despite the previously identified drivers. However, authors in some cases also provide enablers or solutions, which have the potential to cancel out inhibitors and result in a situation in which the drivers described previously are sufficient to incentivize firms to proactively adopt CE practices. Both inhibitors and enablers have been divided into financial, technological, societal, informational, and institutional, although it is acknowledged that these partly interact with each other [35]. This classification was developed by synthesizing data from the analysis of the literature-while there may be more minor categories applicable in individual countries or industries, inhibitors and enablers belonging to the following categories are repeatedly proposed by multiple authors. 


\subsubsection{Financial}

Significant up-front investments to implement CE practices, specifically cleaner production technology and industrial symbiosis material exchange systems, are a large challenge for firms $[17,19,35,44,55,57]$. CE practices might also cause ongoing costs due to higher managements' requirements as firms engage in more horizontal and vertical relationships simultaneously $[8,16,37,39,50,68]$. Ironically, investment recovery often depends on rising resource prices caused by increasing scarcity [15] or green purchasing behaviour by consumers, which is uncertain [68,74].

A large number of authors $[1,17,38,50,55,60,64,71]$ therefore identify better access to and more funding, especially for investments in technology, as critical for firms to implement CE practices. Rizos et al. [74] claim that this is especially vital for small and medium-sized enterprises (SMEs) that struggle to finance investments in technology. Feng and Yan [57] and Geng and Doberstein [16] propose a mix of subsidies that may need to go beyond standard market-based regulatory mechanisms, or loans, which is later corroborated by Mathews and Tan [17] and Pan et al. [35]. Preferential taxes are also frequently mentioned $[22,35,38,44,45,59]$.

In firms themselves, investment is prevented by short-term corporate agendas $[64,68]$ or because of a lack of environmental awareness by management [38]. Securing senior management support for CE initiatives thus remains difficult as managerial reward systems focus on the achievement of immediate goals instead of transformative organizational change [68].

\subsubsection{Technological}

One inhibitor that sits on the interchange of technology and institutions is the unattractiveness of recycled material caused by their comparatively higher prices than virgin materials of similar quality which prevents their use $[1,15,52,82]$. This is also connected to the technical challenge of separating the bio- from the techno-cycle to enable high quality recycling materials $[37,79]$.

Overall directly competing technologies and processes utilized in the linear economy are more accessible and cheaper than those associated with the CE as they have existed longer and received more funding in the past [35]. It will therefore be difficult for sustainable technologies to compete in the absence of additional support [64]. Rizos et al. [74] specify that this issue goes beyond the availability of technology, but extends to lacking organizational capacity on how to integrate and use such technologies, especially in smaller firms.

While a number of industrial symbiosis case studies are given in the literature $[20,26,55]$, the development of technology to allow for mutually beneficial exchanges between firms and new applications of by-products and waste remains a challenge, as is echoed in frequent calls for more funding on and development of technology specifically $[14,16,29,54,60,71,72,77]$. This is based on the claim that (a lack of) technology is a bottleneck for further environmental, particularly recycling and industrial symbiosis improvements [59], which is corroborated in case studies $[21,23,56]$. Murray et al. [2], however, argue that current supposedly green technology is based on scarce and environmentally questionable resources, such as rare earths, highlighting the need to go beyond the improvement of existing technologies.

\subsubsection{Societal}

On the societal level, the main challenge is that influential actors do not see environmental pollution or impending resource scarcity as pressing concerns, also as the required change necessary to transition to a CE will require re-thinking current organizational, institutional and societal paradigms $[50,80]$. While the literature, particularly on China as a country heavily affected by environmental pollution [46,63], cautiously sees a paradigm shift [2], this does not necessarily translate into changes in consumer behaviour [70,71,79], enthusiasm by firms [38,68], or governmental support or incentives to transition [15,44,45]. Bocken et al.'s [67] recent study of Standard \& Poor 
(S\&P) 500 firms' uptake of the CE concept shows that while the CE is present in business, academia, and policy, more radical CE business models are not considered by large companies. Authors therefore propose governments to actively promote public participation in and generate preferences for green products $[13,15,16,44,57,69,74]$. This is to achieve higher recycling rates and general conservation of resources $[59,71]$ as part of a conservation-oriented society [16], as well as allow firms to monetize CE activities by asking for higher prices [68] or sell remanufactured products [70]. Geng and Doberstein [16] note that the Chinese government is currently ill-equipped to generate such participation however, and Xue et al. [72] find that Chinese officials focus on the CE development of industry rather than on public participation. Eco-labelling or certification of firms and products are most commonly cited as tools to generate such awareness and willingness to pay $[13,16,20,44]$, although consumers do not necessarily trust such labels [68,71], and the power of such labels to reliably alter consumption behaviours is questioned [79].

In research on implementation, despite an alleged systems thinking approach and the consideration for the wider consequences of economic activity of the $\mathrm{CE}$, the social dimension is less prominent (compare [2,15]), which is expected to reduce outcomes of implementation projects [59]. The studies by Liu et al. [47] and Scheepens et al. [37] expand the scope of analysis to include third parties, such as residents or society, and this can be seen as first steps towards the stronger inclusion of the social dimension that is critical to the success of the CE [80].

\subsubsection{Informational}

As for informational inhibitors, Sarkis and Zhu [81] highlight a lack of environmental information disclosure systems to make relevant information public and guide further policy efforts as well as enforce compliance through fines, etc., which is corroborated by Geng et al. [58] and Su et al. [46]. There is currently no single accepted CE indicator system; a set of indicators proposed by the Chinese National Development and Reform Commission (NDRC) is criticized because of the absence of micro-level and social indicators [58], while Zhang et al. [28] note that the agencies overseeing the development of EIPs in China use different indicators, which stifles planning and assessment. Su et al. [46] state that the NDRC indicators are applied at the meso- and macro-levels, but note that $99.88 \%$ of manufacturing firms in China are SMEs. A single indicator system on the micro-level however would not be feasible; industry-specific indicators are proposed instead [46].

Apart from the value of such systems for policy, Chen [51] focuses on the value of information sharing for firms; it is specified that this is needed to optimize reduction, reuse, and recycling outcomes [16] and plans for collaboration on CE targets [57]. Su et al. [46] (p. 18) state that information sharing systems should be used by firms and authorities to "find more environmentally and financially beneficial ways to plan and manage their resources".

\subsubsection{Institutional}

A number of previously described inhibitors tie into the institutional environment, which many authors call upon to provide solutions. There is consensus among authors that the current regulative environment favours the linear economy and thus impedes the development of the CE $[1,15,20,23,44,50,61,63,64,74]$. Examples of this are low taxes on virgin material industries that prevent the development of recycling industries, or tax exemptions on products such as coal or batteries [16]. This uneven playing field is also caused by inadequate internalization of externalities produced by polluters through environmental taxes or charges $[1,3,60]$.

A number of authors $[27,35,44,63]$ envision changing this through top-down adjustments of energy or resource prices, particularly fossil fuels, to reflect their scarcity or the pollution caused by them, increasing the viability of recycling and clean or renewable energy sources [15]. Authors also propose taxes, pollution abatement and emission-trading, as well as fines and charges to polluters to internalize externalities $[1,49,63,81]$ as part of the "polluter pays" approaches. The assumption is that this would increase costs for polluting or inefficient firms and therefore incentivize firms to 
make investments in more environmentally friendly operations [1] - Yong [63] (p. 128) states that "enforcement of ... pollution abatement will create an enabling environment".

A similar bias is observable in the claim that current progress indicators are misconstruing human progress, with gross domestic product (GDP) given as the most prominent example $[57,72]$. Mathews and Tan [17] therefore claim that the CE is more interested in throughput than raw GDP growth and Andrews [64] frames the GDP figure as a legacy of an unsustainable linear economy. Implementation studies therefore attempt to put GDP figures into perspective by combining them with measures of (resource) efficiency or productivity [26,44,71] or by drafting more inclusive indicators [57].

Given the importance of the recycling industry that results in cheap, high quality recycled materials for the CE, financial support through subsidies and other incentives as well as investment support for technology development are believed to be vital $[16,35,52,59,63,82]$ and, in combination with top-down planning, has resulted in some success in China [60].

Lastly, scholars are sceptical about governments' ability to enforce CE related regulations, although these claims have so far been specific to the Chinese context. Feng and Yan [57] state that policies need to be well defined and unambiguous to ensure enforceability and Mathews and Tan [17] propose involving several levels of government in the process of enforcement.

\subsection{Circular Economy Supply Chain Configurations}

Three distinct SC configurations have been identified during the SLR: eco-industrial parks, environmental or green SCs, and closed-loop SCs.

\subsubsection{Eco-Industrial Parks}

EIPs, implemented as pilot projects in China, based on the early industrial ecology example of Kalundborg, Denmark [16,17], represent a geographically bounded form of SC that attempts to close resource flows by horizontal and vertical circulation of waste and by-products of collocated firms $[10,16,21,26]$ and create efficiencies by sharing infrastructure $[20,28,45,81]$. In terms of performance, optimistic case studies outweigh negative ones (e.g., [20,21,23,26]), although Zhang et al. [28] (p. 508) remark that EIP pilot projects in China "suffer from a lack of necessary supervision ... many of the approved EIPs slack off after they get their title", with others offering reasons $[27,29]$.

Other barriers include the willingness and ability of EIPs' firms to share information and cooperate [20,47], especially when going beyond individual EIPs to connect several, and take advantage of, more symbiotic relations as envisioned by Sarkis and Zhu [81]. Others [19,48] find that trust and relationship building are vital to enable the transition from conventional industrial parks to EIPs, in which local authorities can act as facilitators. Wang et al. [25] follow this idea and investigate the development of a coordination network between local authorities to foster industrial symbiosis, finding that institutional capacities benefit firms to engage industrial symbiosis by promoting relational links across industry and government; Shi and $\mathrm{Yu}[24]$ and others $[22,27,48]$ therefore propose the government as an enabler or facilitator to develop relationships between firms and thus EIPs. Zeng et al. [6] expand the scope to include various institutional pressures and find that they improve circular performance of EIPs.

In this regard, Aid et al. [49] claim that waste management firms can also provide support services but would need to comprehensively alter existing business models, which creates risk from their perspective.

Apart from the industrial symbiosis aspect of EIPs, resource efficiency practices at this production stage are "generally recognized as 'cleaner production'" [17] (p. 436) and aim to increase the utilization of energy, water, and raw materials, as well as decrease resulting pollution [20,23,36,46,61]. However, given the increasingly stringent environmental regulations in China and elsewhere, cleaner production is not a unique feature of EIPs $[16,26]$. Nevertheless, in China the practice of CE "was mainly reflected 
in the promotion of efficiency and quality of material circulation and energy utilization" [26] (p. 212). One particularly important aspect is to prevent hazardous or toxic waste $[14,44,72]$.

Mathews and Tan [17] note that while industrial ecology is mainly implemented at the meso-levels of EIPs, there are studies that scrutinize the application of the same principles for entire industries [45,47], national infrastructure systems [56], and national economies [53]. Shi and Yu [24] (p. 6329) therefore claim that "EIPs can continually move from strategic niches into the mainstream of industrial development in China".

\subsubsection{Environmental, Sustainable, and Green Supply Chains}

The second SC configuration is the environmental, sustainable, or green SC. This configuration goes beyond the geographic boundaries of EIPs to include suppliers and customers, and aims to increase a variety of efficiencies (most notably logistics, storage, packaging, purchasing, etc.) across the SC $[9,10,39-43,81]$ with the end result of preventing waste and increasing resource utilization [16]. Authors $[10,81]$ show that firms implementing environmental SC cooperation with suppliers and customers as well as green purchasing, are also more successful at implementing CE practices and enjoy associated environmental and economic performance gains [40], especially when going beyond organizational boundaries [20,39,40]. Genovese et al. [32] argue similarly and claim that integrating CE and green SC management principles brings further environmental benefits, although economic viability remains dependent on governmental support in their study. Zhu et al. [41] find that small and medium-sized Chinese companies lag behind in green SC management practices in comparison to Japanese competitors, which is also explained by Japanese firms as being motivated by more environmentally aware consumers. Shahbazi et al. [38] find that on the micro-level firms struggle to increase material efficiency because of internal barriers, namely a lack of investment, necessary knowledge and skills, and information-sharing.

Sarkis and Zhu [81] therefore highlight the need for inter-organizational innovation and IT to enable such cooperation and propose managerial and organizational techniques such as Total Quality Environmental Management (TQEM) and environmental management systems (EMS) to implement such initiatives. Zhu et al. [10] name Internal Environmental Management (IEM), but also describe the organizational challenges this places on firms-firms should thus focus on the reduction aspect of the 3Rs (i.e., reduce, reuse, recycle) due the potential for direct cost savings which might motivate capacity-building initially [20].

\subsubsection{Closed-Loop Supply Chains}

Closed-loop SC configurations are scarcely analysed in empirical papers [34], with more frequent mentions of closed-loop systems [2], or more general closed-loop material flows [16,72]. While loop closing is typically associated with efforts at the production side, e.g., EIPs, closed-loop SCs follow the same principle and extend this rationale to the entire life-cycle of the product [60]. Genovese et al. [32] distinguish between open-loop chains involving materials from several producers and closed-loop chains focusing on a particular manufacturer. In both cases, the main purpose is reusing and recovering added value and avoiding waste, which is supported by reverse logistics [81] and the management of integrated secondary markets [30]. Furthermore Park et al. [36] and Tukker [8] identify product and business model design as challenges to monetize closed-loop SCs and subsequent changes in the relationship between producer and consumer.

While designing products to be upgraded, repaired, refurbished, and remanufactured to counter obsolescence and degradation of physical product artefacts are a critical component of the CE and tie into closed-loop SCs $[2,20,32,36,37,66]$, this remains difficult and will require a comprehensive design paradigm shift $[8,9,64,65]$. A variety of concepts are proposed here: biomimicry [64], green design [36], eco-design [20,65] and cradle-to-cradle design [2,14,32,79]. Bocken et al. [9] expand on this and give an overview of product and business model design archetypes that allow for loop-closing; Hollander et al. [65] specify that eco-design and product design that allow for circularity are necessary, 
which they break down further into design for product integrity and design for recycling-from which it becomes clear that products that allow for loop-closing do not necessarily result in immediate material or energy savings. Zink and Geyer [18] therefore warn that if repaired, refurbished and remanufactured goods in the $\mathrm{CE}$ are not adequate substitutes for newly manufactured goods, the environmental benefits of these activities will be reduced or negated through what they coin "circular economy rebound".

Embedding such novel products in profitable business models to recuperate the investment in the product and support the SC infrastructure is another challenge $[7-9,14,70,73,74]$ that in some cases hinges on top-down intervention or subsidies to become feasible [37] or might not be financially successful despite superior environmental performance [34]. Product-service systems (PSSs) are claimed to be one possible vehicle to monetize design and maintenance efforts through long-term customer relationships, but are difficult to implement successfully due to SC infrastructure requirements and persisting consumer reservations $[7,8]$, especially if the subsequent product should be remanufactured instead of being new [70]. Jensen and Remmen [33] strengthen the argument for PSSs by showing how product stewardship initiatives in a number of industries have engendered environmentally better end-of-life management and Mendoza et al. [73] provide a framework on how firms can innovate and transition to such novel business models. One impactful barrier that is likely to prevent such transitions from taking place is the need for agreement across SCs; Rizos et al. [74] find that even if SMEs are willing to adopt new business models, their low power in their supply network prevents them from convincing important partners to collaborate.

Despite Gircuo et al.'s [14] (p. 440) proposal of using additive manufacturing to improve "affordability of manufacturing replacement parts" and circumvent the infrastructure requirements by letting consumers perform upgrades and repair items themselves, most authors $[8,10,16,32,77]$ thus envision this infrastructure as developed by firms' SCs. Reverse SC logistics are proposed towards this end $[2,10,30,78,81]$. Winkler [39] states that closed-loop SCs need to be established on a network level, which increases the potential for environmental and economic benefits. However, information and coordination efforts rise with the size of the network, which mirrors the claims by Geng and Doberstein [16] and Jensen and Remmen [33] that information requirements are a considerable barrier to closed-loop SCs.

On the consumer side Hazen et al. [70] find that consumers perceive remanufactured items as less desirable and are typically not prepared to adopt them unless further incentives are given or there are pre-existing positive attitudes. Similarly van Buren et al. [50] and Tukker [8] claim that PSSs and other leasing or renting models cause perceived risk due to the lack of ownership by the consumer; furthermore there is a general preference for ownership due to culture and reputation associated to owning products, which Pialot et al. [66] seek to balance with upgradable PSSs that are more attractive to consumers. Strengthening trust and fostering a different consumer culture [79] has been explored to some degree using eco-labels and informational campaigns, but difficulties remain as shown previously $[20,34,44]$. In China, Liu and Bai [68] find that only $3 \%$ of consumers are influenced by such labels in their purchasing decisions.

\section{Discussion}

This section will discuss the descriptive and thematic results of the SLR.

\subsection{Discussion of Descriptive Results}

While it is clear that the number of publications on the CE are increasing, there is also a trend in the journals that are targeted by authors. There is an overall bias towards environmentally-oriented engineering journals (most notably Journal of Cleaner Production and Journal of Industrial Ecology) and recycling and waste management journals. However, especially from 2013 onwards, journals less focused on engineering such as Economy and Society, Local Economy, Journal of Business Ethics, and Sustainability have published articles on the CE as authors $[2,15,50,79]$ move to embrace the wider social and economic aspects of the CE. Meanwhile a similar shift is beginning in the Journal of Industrial 
Ecology [18]. As the CE concept is progressing in the academic discourse, this highlights the wide range of disciplines that hold interest in the topic on the one hand, but also shows how the concept itself is becoming ever more expansive on the other. Attempts to reconcile the engineering/implementation perspective with the broader economic and social system perspective are methodologically difficult however (compare [37]).

Looking at this trend geographically, this split is to some extent attributed to the differences in Chinese and Western-centric research. While the initial CE publications were essentially reviews of the Chinese cleaner production and CE policies, the implementation studies following this were largely occupied with planning and evaluating pilot project EIPs and cities or regions in China using substance-flow- and material-flow-analysis (e.g., [26]). However, despite it being recognized early in Chinese research that society or consumers need to participate if the concept is to be successful $[13,16,62]$, the framing of the $\mathrm{CE}$ as a top-down policy makes the inclusion of these stakeholders difficult. Liu et al.'s [42] study is a rare attempt at utilizing a mixed-integral programming model, under which optimum outcomes for different stakeholders are computed in different scenarios. Naustdalslid [15] later summarizes this understanding of the CE as having a notion of "scientific social engineering" tied to the political vision of a harmonious society based on economic prosperity and a pollution-free environment.

After 2013, publications on the CE outside of China increased and the debate was being led by think-tanks, such as the EMF, that frame the CE less as an economic strategy as in China, but more as a human development model $[2,15]$, which is to be transitioned to through micro-level action by environmentally conscious firms and individuals. In the absence of firm commitments by European or North American governments to CE-specific policies, studies on firms and SCs that attempt to overcome organizational and financial barriers have advanced the concept further [50,74].

\subsection{Discussion of Thematic Results}

Considering the first research question, which asked what overarching goals and assumptions define the $\mathrm{CE}$, the wealth of proposed antecedents and scopes makes a simple answer difficult. The CE currently retains a sustainability/engineering impetus as is evident in the enduring connection to cleaner production and industrial ecology as antecedents. Synthesizing insights from across the spectrum, this paper has identified four core principles that unify all knowledge bases: (a) the CE as a regenerative and restorative economic framework, which (b) decouples economic growth from environmental degradation and which (c) seeks to preserve economic, social, and environmental value while, d) contributing to system resilience.

We therefore propose that the CE is understood as a common set of goals and assumptions rather than a prescriptive set of practices as research and practice on the implementation of the CE continues to evolve. As such, our definition differs from Geissdorfer et al.'s [85] (p. 766) recent definition of the $C E$ that focuses on mechanisms and practices "as a regenerative system in which resource input and waste, emission and energy leakage are minimized by slowing, closing, and narrowing material and energy loops. This can be achieved through long-lasting design, maintenance, repair, reuse, remanufacturing, refurbishing, and recycling".

This is because we argue that there is a danger that the means of the CE are being confused with the ends, as is common in CE definitions that equate the concept to an individual antecedent. While there is a great variety of strategies for implementing the $\mathrm{CE}$, some of which derive directly from certain antecedents of the concept that have fed into practice recommendations on the meso-level of SCs, it is likely that new strategies are being developed continuously. For example, novel business models have a fit with the CE, but go beyond how it is currently implemented $[9,66,86]$. We therefore propose that the assumption that any given current antecedent or set of antecedents is equal to the $\mathrm{CE}$, even if described as a more general mechanism or practice, risks limiting the concept to how it is currently implemented for conceptual, financial, or technological reasons, which would prevent future advances from being integrated in the $\mathrm{CE}$, and goes against the notion of opening up the 
$\mathrm{CE}$ as a common space for sustainability [75]. Concerning Geissdorfer et al.'s [85] findings that the relationship between the $\mathrm{CE}$ and sustainability is either conditional, beneficial, or a trade-off, we would agree that the $\mathrm{CE}$ is conditional in terms of goals, but propose it be inclusive of new mechanisms and practices.

Coming to the second research question about practices attributed to the meso-level of SCs in the $\mathrm{CE}$, practices discovered in the literature were clustered into three SC configurations that authors connect to the CE in research: EIPs, environmental, sustainable, or green, SCs, and lastly closed-loop SCs. Practices in each configuration are similar to those proposed earlier under these labels-no distinct new practices on the meso-level have emerged as yet as a result of the increasing popularity of the CE concept, also as research typically does not integrate them into a CSC featuring all described practices.

Concerning the third research question about the conditions necessary for such SC configurations to emerge, drivers that incentivize a pursuit of CE practices from the perspective of a firm or SC, particularly at the manufacturing stage, were identified, which arise directly from the most prominent antecedents in cleaner production and industrial ecology $[16,26,62]$. These practices feature strongly in EIPs, where they can increase efficiency, transform potentially polluting waste into a resource, and reduce costs for collocated businesses. Challenges for this SC configuration are rooted in a complex web of inhibitors, many of which are outside the area of influence of the affected business. Access to funding and technology, cited here as establishing EIPs, is associated with higher costs initially and creates more dependency between actors long-term. It therefore appears that such initiatives remain dependent on government funding in the form of subsidies or other support in the absence of cheaper technology, rising resource prices, or environmentally-minded consumers $[16,36]$. Similar issues are identified for green or environmental SCs; while such initiatives can result in efficiency gains [10,43], the difficulty and cost of transitioning are amplified by organizational challenges. Kok et al. [87] refer to short-term agendas in this regard and Liu and Bai [68] find that decision-makers in firms do not engage with the CE concept due to structural, cultural, and contextual factors. While immediate efficiency through sustainable SC management, for example gains, is an adequate incentive [36], the more ambitious, transformative aspects of the $\mathrm{CE}$ are not seen as viable in competitive environments [67]. Liu and Bai [68] (p. 150) succinctly state: "without appropriate regulations, most firms would not actively develop a circular economy".

This is most visible for closed-loop SCs that go beyond the geographically isolated EIPs and functionally-specific green or environmental SC management initiatives, but require integration with product designs and business models $[9,64,66]$ and a comprehensive reverse logistics infrastructure $[32,81]$ if they are to utilize remanufacturing and other secondary production strategies. While there are promising approaches available that could tie such initiatives together, most notably leasing and PSS business models [8], financial and organizational difficulties exist in each of these areas from the perspective of a firm, as moving away from linear paradigms will challenge entrenched linear thinking patterns, although recent research finds that firms are becoming more open [74]. More than the two previous SC configurations, however, closed-loop SCs are also more affected by the uncertainty caused by potentially changing consumer preferences as they engender different products and customer relationships. Whether leasing, PSS, and other business models that sell access instead of ownership can be applied to a wide range of goods in business-to-consumer (B2C) contexts remains to be seen, given that the "take-make-use-dispose" pattern based on ownership is the dominant consumer culture $[8,64]$. Similarly a large proportion of expected pollution and resource savings of the CE is to be achieved by circulating existing goods for longer through remanufacturing [18] - but whether consumers are prepared to adopt those remains questionable [70].

Further developing green product preferences and long-time horizons in business and consumer culture will therefore be a major challenge if firms and SCs are to move towards CSCs and business models that integrate the other identified SCs configurations. 


\section{Conclusions}

This paper has systematically reviewed the body of CE literature to identify common ground in $\mathrm{CE}$ definitions and understandings, and scrutinize the implementation of the concept in the form of its three SC configurations.

It is concluded that the variety of antecedents attributed to the CE make convergence to a single definition difficult. However, it might be argued that an overly narrow understanding would harm such an ambitious vision, following Blomsma and Brennan's [75] (p. 603) claim that the CE offers "a new cognitive unit and discursive space for debate". By integrating the fast-growing but diverse wealth of existing knowledge through an SLR, this article contributes to this debate by synthesizing four goals that underpin current CE research. These goals can serve as anchoring points for future research and call for more differentiated enquiries that go beyond studies mirroring individual antecedents of the $\mathrm{CE}$, such as industrial symbiosis, but instead take a more holistic perspective to include more stakeholder groups, such as consumers and local governments.

Furthermore, it was shown that three SC configurations have emerged that fit the CE concept: EIPs; environmental, sustainable, or green SCs; and closed-loop SCs. A number of drivers, enablers, and inhibitors can be expected to determine the success and feasibility of implementation of their associated practices. Overall, the current competitive environment poses several challenges for these configurations, which require further investigation.

Given the importance of moving beyond a pure engineering understanding of the CE, EIPs and industrial symbiosis studies would especially benefit from widening the analysis to include more stakeholders that might be affected by more interconnected production systems (compare $[6,25,47]$ ).

In highly competitive business environments, the implementation of green and environmental SC practices remains difficult_-challenging existing paradigms in industry will necessitate establishing under which conditions such investments are not only socially and environmentally desirable, but profitable in the short- and long-term [35,74].

Closed-loop SCs imply the most profound change for firms and consumers and a variety of new spaces are opening up. One problem here is designing product offerings that do not engender rebound effects [18] while remaining attractive to consumers. The issue of a lack of ownership and newness because of leasing or PSS business models [8] in combination with remanufactured items [70] is particularly challenging as this breaks with the dominant current consumer culture.

Lastly, integrating the different SC configurations into a truly CE supply configuration and then aligning it to a commercial strategy in the absence of strong government support remains difficult in theory and practice.

A potential limitation of this paper is that on the micro-level of practices it was not possible to cleanly differentiate between an SC, product design, commercial strategy, and the greater business model perspective. As per the research question and given the focus of the literature itself, the SC perspective was made the centrepiece, but it has to be acknowledged that the CE as a comprehensive concept will ultimately impact on all three functions if it is to be successfully implemented. Disregarding the importance of product design and commercial strategy would therefore have weakened the findings of this study.

Acknowledgments: We would like to thank two anonymous reviewers for their insightful comments and suggestions, which led to an improvement of the work.

Author Contributions: Donato Masi developed the research aims and structured the thematic analysis. Donato Masi and Steven Day developed the review questions and performed the literature search, selection, and review. Steven Day wrote the paper. Janet Godsell provided assistance regarding the paper's structure and presenting its findings.

Conflicts of Interest: The authors declare no conflict of interest. 


\section{References}

1. Andersen, M.S. An introductory note on the environmental economics of the circular economy. Sustain. Sci. 2007, 2, 133-140. [CrossRef]

2. Murray, A.; Skene, K.; Haynes, K. The circular economy: An interdisciplinary exploration of the concept and application in a global context. J. Bus. Ethics 2017, 140, 369-380. [CrossRef]

3. Hoornweg, D.; Bhada-Tata, P. What a waste: A global review of solid Waste Man; Urban Development Series Knowledge Papers; World Bank: Washington, DC, USA, 2012.

4. Ellen MacArthur Foundation. Towards the Circular Economy 3-Accelerating the Scale-Up across Global Supply Chains; Ellen MacArthur Foundation: Cowes, UK, 2014. Available online: http:/ /www.ellenmacarthurfoundation. org/books-and-reports (accessed on 12 June 2017).

5. Hertwich, E.G. Consumption and the Rebound Effect: An industrial ecology perspective. J. Ind. Ecol. 2005, 9, 85-98. [CrossRef]

6. Zeng, H.; Chen, X.; Xiao, X.; Zhou, Z. Institutional pressures, sustainable supply chain management, and circular economy capability: Empirical evidence from Chinese eco-industrial park firms. J. Clean. Prod. 2017, 155, 54-65. [CrossRef]

7. Fischer, A.; Pascucci, S. Institutional incentives in circular economy transition: The case of material use in the Dutch textile industry. J. Clean. Prod. 2017, 155, 17-32. [CrossRef]

8. Tukker, A. Product services for a resource-efficient and circular economy-A review. J. Clean. Prod. 2015, 97, 76-91. [CrossRef]

9. Bocken, N.M.; de Pauw, I.; Bakker, C.; van der Grinten, B. Product design and business model strategies for a circular economy. J. Ind. Prod. Eng. 2016, 33, 308-320. [CrossRef]

10. Zhu, Q.; Geng, Y.; Lai, K.H. Circular economy practices among Chinese manufacturers varying in environmental-oriented supply chain cooperation and the performance implications. J. Environ. Manag. 2010, 91, 1324-1331. [CrossRef] [PubMed]

11. Tranfield, D.; Denyer, D.; Smart, P. Towards a methodology for developing evidence-informed management knowledge by means of systematic review. Br. J. Manag. 2003, 14, 207-222. [CrossRef]

12. Denyer, D.; Tranfield, D. Producing a systematic review. In The Sage handbook of Organizational Research Methods; Buchanan, D.A., Bryman, A., Eds.; Sage Publications Ltd.: Thousand Oaks, CA, USA, 2009; pp. 671-689.

13. Yuan, Z.; Bi, J.; Moriguichi, Y. The circular economy: A new development strategy in China. J. Ind. Ecol. 2006, 10, 4-8. [CrossRef]

14. Giurco, D.; Littleboy, A.; Boyle, T.; Fyfe, J.; White, S. Circular economy: Questions for responsible minerals, additive manufacturing and recycling of metals. Resources 2014, 3, 432-453. [CrossRef]

15. Naustdalslid, J. Circular economy in China-The environmental dimension of the harmonious society. Int. J. Sustain. Dev. World Ecol. 2014, 21, 303-313. [CrossRef]

16. Geng, Y.; Doberstein, B. Developing the circular economy in China: Challenges and opportunities for achieving 'leapfrog development'. Int. J. Sustain. Dev. World Ecol. 2008, 15, 231-239. [CrossRef]

17. Mathews, J.A.; Tan, H. Progress toward a Circular Economy in China: The Drivers (and Inhibitors) of Eco-industrial Initiative. J. Ind. Ecol. 2011, 15, 435-457. [CrossRef]

18. Zink, T.; Geyer, R. Circular economy rebound. J. Ind. Ecol. 2017, 21, 593-602. [CrossRef]

19. Ceglia, D.; de Abreu, M.C.S.; da Silva Filho, J.C.L. Critical elements for eco-retrofitting a conventional industrial park: Social barriers to be overcome. J. Environ. Manag. 2017, 187, 375-383. [CrossRef] [PubMed]

20. Hu, J.; Xiao, Z.; Zhou, R.; Deng, W.; Wang, M.; Ma, S. Ecological utilization of leather tannery waste with circular economy model. J. Clean. Prod. 2011, 19, 221-228. [CrossRef]

21. Li, Y.; Ma, C. Circular economy of a papermaking park in China: A case study. J. Clean. Prod. 2015, 92, 65-74. [CrossRef]

22. Liu, Z.; Adams, M.; Cote, R.P.; Geng, Y.; Chen, Q.; Liu, W.; Sun, L.; Yu, X. Comprehensive development of industrial symbiosis for the response of greenhouse gases emission mitigation: Challenges and opportunities in China. Energy Policy 2017, 102, 88-95. [CrossRef]

23. Ma, S.; Hu, S.; Chen, D.; Zhu, B. A case study of a phosphorus chemical firm's application of resource efficiency and eco-efficiency in industrial metabolism under circular economy. J. Clean. Prod. 2015, 87, 839-849. [CrossRef] 
24. Shi, L.; Yu, B. Eco-industrial parks from strategic niches to development mainstream: The cases of China. Sustainability 2014, 6, 6325-6331. [CrossRef]

25. Wang, Q.; Deutz, P.; Chen, Y. Building institutional capacity for industrial symbiosis development: A case study of an industrial symbiosis coordination network in China. J. Clean. Prod. 2017, 142, 1571-1582. [CrossRef]

26. Wen, Z.; Meng, X. Quantitative assessment of industrial symbiosis for the promotion of circular economy: A case study of the printed circuit boards industry in China's Suzhou New District. J. Clean. Prod. 2015, 90, 211-219. [CrossRef]

27. Yu, C.; Dijkema, G.P.; Jong, M. What Makes Eco-Transformation of Industrial Parks Take Off in China? J. Ind. Ecol. 2015, 19, 441-456. [CrossRef]

28. Zhang, L.; Yuan, Z.; Bi, J.; Zhang, B.; Liu, B. Eco-industrial parks: National pilot practices in China. J. Clean. Prod. 2010, 18, 504-509. [CrossRef]

29. Zhu, Q.; Geng, Y.; Sarkis, J.; Lai, K.H. Barriers to Promoting Eco-Industrial Parks Development in China. J. Ind. Ecol. 2015, 19, 457-467. [CrossRef]

30. Dhakal, M.; Smith, M.H.; Newbery, R. Secondary market: A significant aspect in reverse logistics and sustainability. Int. J. Soc. Sustain. Econ. Soc. Cult. Context 2016, 12, 24-35. [CrossRef]

31. Ferreira, M.A.; Jabbour, C.J.C.; Jabbour, A.B.L.S. Maturity levels of Material Cycles and Waste Management in a context of green supply chain management: An innovative framework and its application to Brazilian cases. J. Mater. Cycles Waste Manag. 2015, 1, 516-525. [CrossRef]

32. Genovese, A.; Acquaye, A.A.; Figueroa, A.; Koh, S.L. Sustainable supply chain management and the transition towards a circular economy: Evidence and some applications. Omega 2017, 66, 344-357. [CrossRef]

33. Jensen, J.P.; Remmen, A. Enabling Circular Economy through Product Stewardship. Procedia Manag. 2017, 8, 377-384. [CrossRef]

34. Nasir, M.H.A.; Genovese, A.; Acquaye, A.A.; Koh, S.C.L.; Yamoah, F. Comparing linear and circular supply chains: A case study from the construction industry. Int. J. Prod. Econ. 2017, 183, 443-457. [CrossRef]

35. Pan, S.Y.; Du, M.A.; Huang, I.T.; Liu, I.H.; Chang, E.E.; Chiang, P.C. Strategies on implementation of waste-to-energy (WTE) supply chain for circular economy system: A review. J. Clean. Prod. 2015, 108, 409-421. [CrossRef]

36. Park, J.; Sarkis, J.; Wu, Z. Creating integrated business and environmental value within the context of China's circular economy and ecological modernization. J. Clean. Prod. 2010, 18, 1494-1501. [CrossRef]

37. Scheepens, A.E.; Vogtländer, J.G.; Brezet, J.C. Two life cycle assessment (LCA) based methods to analyse and design complex (regional) circular economy systems. Case: Making water tourism more sustainable. J. Clean. Prod. 2016, 114, 257-268. [CrossRef]

38. Shahbazi, S.; Wiktorsson, M.; Kurdve, M.; Jönsson, C.; Bjelkemyr, M. Material efficiency in manufacturing: Swedish evidence on potential, barriers and strategies. J. Clean. Prod. 2016, 127, 438-450. [CrossRef]

39. Winkler, H. Closed-loop production systems-A sustainable supply chain approach. CIRP J. Manuf. Sci. Technol. 2011, 4, 243-246. [CrossRef]

40. Winkler, H.; Kaluza, B. Sustainable supply chain networks-A new approach for effective Waste Management. WIT Trans. Ecol. Environ. 2006, 92, 501-510.

41. Zhu, Q.; Qu, Y.; Geng, Y.; Fujita, T. A comparison of regulatory awareness and green supply chain management practices among Chinese and Japanese manufacturers. Bus. Strategy Environ. 2017, 26, 18-30. [CrossRef]

42. Zhu, Q.; Geng, Y.; Lai, K.H. Environmental Supply Chain Cooperation and Its Effect on the Circular Economy Practice-Performance Relationship among Chinese Manufacturers. J. Ind. Ecol. 2011, 15, 405-419. [CrossRef]

43. Zhu, Q.; Geng, Y.; Sarkis, J.; Lai, K.H. Evaluating green supply chain management among Chinese manufacturers from the ecological modernization perspective. Trans. Res. E Log. Trans. Rev. 2011, 47, 808-821. [CrossRef]

44. Geng, Y.; Zhu, Q.; Doberstein, B.; Fujita, T. Implementing China's circular economy concept at the regional level: A review of progress in Dalian, China. Waste Manag. 2009, 29, 996-1002. [CrossRef] [PubMed]

45. Ma, S.H.; Wen, Z.G.; Chen, J.N.; Wen, Z.C. Mode of circular economy in China's iron and steel industry: A case study in Wu'an city. J. Clean. Prod. 2014, 64, 505-512. [CrossRef]

46. Su, B.; Heshmati, A.; Geng, Y.; Yu, X. A review of the circular economy in China: Moving from rhetoric to implementation. J. Clean. Prod. 2013, 42, 215-227. [CrossRef] 
47. Liu, D.; Li, H.; Wang, W.; Dong, Y. Constructivism scenario evolutionary analysis of zero emission regional planning: A case of Qaidam Circular Economy Pilot Area in China. Int. J. Prod. Econ. 2012, 140, 341-356. [CrossRef]

48. Yu, C.; de Jong, M.; Dijkema, G.P. Process analysis of eco-industrial park development-The case of Tianjin, China. J. Clean. Prod. 2014, 64, 464-477. [CrossRef]

49. Aid, G.; Eklund, M.; Anderberg, S.; Baas, L. Expanding roles for the Swedish Waste Management sector in inter-organizational resource management. Resour. Conserv. Recycl. 2017, 124, 85-97. [CrossRef]

50. Van Buren, N.; Demmers, M.; van der Heijden, R.; Witlox, F. Towards a Circular Economy: The Role of Dutch Logistics Industries and Governments. Sustainability 2016, 8, 647. [CrossRef]

51. Chen, J.Z. Material flow and circular economy. Syst. Res. Behav. Sci. 2009, 26, 269-278. [CrossRef]

52. Gregson, N.; Crang, M.; Fuller, S.; Holmes, H. Interrogating the circular economy: The moral economy of resource recovery in the EU. Econ. Soc. 2015, 44, 218-243. [CrossRef]

53. Li, N.; Zhang, T.; Liang, S. Reutilisation-Extended material flows and circular economy in China. Waste Manag. 2013, 33, 1552-1560. [CrossRef] [PubMed]

54. Matus, K.J.; Xiao, X.; Zimmerman, J.B. Green chemistry and green engineering in China: Drivers, policies and barriers to innovation. J. Clean. Prod. 2012, 32, 193-203. [CrossRef]

55. Smol, M.; Kulczycka, J.; Henclik, A.; Gorazda, K.; Wzorek, Z. The possible use of sewage sludge ash (SSA) in the construction industry as a way towards a circular economy. J. Clean. Prod. 2015, 95, 45-54. [CrossRef]

56. Wen, Z.; Li, R. Materials metabolism analysis of China's highway traffic system (HTS) for promoting circular economy. J. Ind. Ecol. 2010, 14, 641-649. [CrossRef]

57. Feng, Z.; Yan, N. Putting a circular economy into practice in China. Sustain. Sci. 2007, 2, 95-101. [CrossRef]

58. Geng, Y.; Fu, J.; Sarkis, J.; Xue, B. Towards a national circular economy indicator system in China: An evaluation and critical analysis. J. Clean. Prod. 2012, 23, 216-224. [CrossRef]

59. Li, J.; Yu, K. A study on legislative and policy tools for promoting the circular economic model for Waste Management in China. J. Mater. Cycles Waste Manag. 2011, 13, 103-112. [CrossRef]

60. Mathews, J.A.; Tang, Y.; Tan, H. China's move to a Circular Economy as a development strategy. Asian Bus. Manag. 2011, 10, 463-484. [CrossRef]

61. Wu, H.Q.; Shi, Y.; Xia, Q.; Zhu, W.D. Effectiveness of the policy of circular economy in China: A DEA-based analysis for the period of 11th five-year-plan. Resour. Conserv. Recycl. 2014, 83, 163-175. [CrossRef]

62. Yap, N.T. Towards a Circular Economy. Greener Manag. Int. 2005, 50, 11-24. [CrossRef]

63. Yong, R. The circular economy in China. J. Mater. Cycles Waste Manag. 2007, 9, 121-129. [CrossRef]

64. Andrews, D. The circular economy, design thinking and education for sustainability. Loc. Econ. 2015, 30, 305-315. [CrossRef]

65. Hollander, M.C.; Bakker, C.A.; Hultink, E.J. Product design in a circular economy: Development of a typology of key concepts and terms. J. Ind. Ecol. 2017, 21, 517-525. [CrossRef]

66. Pialot, O.; Millet, D.; Bisiaux, J. “Upgradable PSS": Clarifying a new concept of sustainable consumption/production based on upgradability. J. Clean. Prod. 2017, 141, 538-550. [CrossRef]

67. Bocken, N.M.; Ritala, P.; Huotari, P. The Circular Economy: Exploring the Introduction of the Concept Among S\&P 500 Firms. J. Ind. Ecol. 2017, 21, 487-490. [CrossRef]

68. Liu, Y.; Bai, Y. An exploration of firms' awareness and behavior of developing circular economy: An empirical research in China. Resour. Conserv. Recycl. 2014, 87, 145-152. [CrossRef]

69. Guo, B.; Geng, Y.; Sterr, T.; Zhu, Q.; Liu, Y. Investigating public awareness on circular economy in western China: A case of Urumqi Midong. J. Clean. Prod. 2017, 142, 2177-2186. [CrossRef]

70. Hazen, B.T.; Mollenkopf, D.A.; Wang, Y. Remanufacturing for the circular economy: An examination of consumer switching behavior. Bus. Strategy Environ. 2017, 26, 451-464. [CrossRef]

71. Liu, Q.; Li, H.M.; Zuo, X.L.; Zhang, F.F.; Wang, L. A survey and analysis on public awareness and performance for promoting circular economy in China: A case study from Tianjin. J. Clean. Prod. 2009, 17, 265-270. [CrossRef]

72. Xue, B.; Chen, X.P.; Geng, Y.; Guo, X.J.; Lu, C.P.; Zhang, Z.L.; Lu, C.Y. Survey of officials' awareness on circular economy development in China: Based on municipal and county level. Resour. Conserv. Recycl. 2010, 54, 1296-1302. [CrossRef]

73. Mendoza, J.M.F.; Sharmina, M.; Gallego-Schmid, A.; Heyes, G.; Azapagic, A. Integrating Backcasting and Eco-Design for the Circular Economy: The BECE Framework. J. Ind. Ecol. 2017, 21, 526-544. [CrossRef] 
74. Rizos, V.; Behrens, A.; Van Der Gaast, W.; Hofman, E.; Ioannou, A.; Kafyeke, T.; Flamos, A.; Rinaldi, R.; Papadelis, S.; Hirschnitz-Garbers, M.; et al. Implementation of circular economy business models by small and medium-sized enterprises (SMEs): Barriers and enablers. Sustainability 2016, 8, 1212. [CrossRef]

75. Blomsma, F.; Brennan, G. The emergence of circular economy: A new framing around prolonging resource productivity. J. Ind. Ecol. 2017, 21, 603-614. [CrossRef]

76. Bonviu, F. The European economy: From a linear to a circular economy. Rom. J. Eur. Aff. 2014, 14, 78-91.

77. Preston, F. A Global Redesign? Shaping the Circular Economy; Chatham House: London, UK, 2012; pp. 1-20.

78. Webster, K. What might we say about a circular economy? Some temptations to avoid if possible. World Futures 2013, 69, 542-554. [CrossRef]

79. Hobson, K. Closing the loop or squaring the circle? Locating generative spaces for the circular economy. Progress Hum. Geogr. 2016, 40, 88-104. [CrossRef]

80. Moreau, V.; Sahakian, M.; Griethuysen, P.; Vuille, F. Coming full circle: Why social and institutional dimensions matter for the circular economy. J. Ind. Ecol. 2017, 21, 497-506. [CrossRef]

81. Sarkis, J.; Zhu, H. Information technology and systems in China's circular economy: Implications for sustainability. J. Syst. Inf. Technol. 2008, 10, 202-217. [CrossRef]

82. Velis, C.A. Circular economy and global secondary material supply chains. Waste Manag. Res. 2015, 33, 389-391. [CrossRef] [PubMed]

83. Ghisellini, P.; Cialani, C.; Ulgiati, S. A review on circular economy: The expected transition to a balanced interplay of environmental and economic systems. J. Clean. Prod. 2016, 114, 11-32. [CrossRef]

84. Lieder, M.; Rashid, A. Towards circular economy implementation: A comprehensive review in context of manufacturing industry. J. Clean. Prod. 2016, 115, 36-51. [CrossRef]

85. Geissdoerfer, M.; Savaget, P.; Bocken, N.M.P.; Hultink, E.J. The Circular Economy-A new sustainability paradigm? J. Clean. Prod. 2016, 143, 757-768. [CrossRef]

86. Kortmann, S.; Piller, F. Open business models and closed-loop value chains. Calif. Manag. Rev. 2013, 58, 88-108. [CrossRef]

87. Kok, L.; Wurpel, G.; Ten Wolde, A. Unleashing the Power of the Circular Economy; Report by IMSA Amsterdam for Circle Economy; IMSA Amsterdam: Amsterdam, The Netherlands, 2013.

(C) 2017 by the authors. Licensee MDPI, Basel, Switzerland. This article is an open access article distributed under the terms and conditions of the Creative Commons Attribution (CC BY) license (http://creativecommons.org/licenses/by/4.0/). 